\title{
Dietary Health-Related Risk Factors for Women in the Polish and Croatian Population Based on the Nutritional Behaviors of Junior Health Professionals
}

\author{
Dominika Głąbska ${ }^{1, *(\mathbb{D})}$, Valentina Rahelić ${ }^{2}{ }^{(\mathbb{D}}$, Dominika Guzek ${ }^{3}{ }^{(0}$, Kamila Jaworska ${ }^{1}$, \\ Sandra Bival ${ }^{2}$, Zlatko Giljević ${ }^{4,5}$ and Eva Pavić ${ }^{2}$ \\ 1 Department of Dietetics, Faculty of Human Nutrition and Consumer Sciences, Warsaw University of Life \\ Sciences (WULS-SGGW), 159c Nowoursynowska Str., 02-776 Warsaw, Poland; kamila_jaworska@onet.eu \\ 2 Department of Nutrition and Dietetics, University Hospital Centre Zagreb, 12 Kišpatićeva Str., \\ 10-000 Zagreb, Croatia; valentina.rahelic@kbc-zagreb.hr (V.R.); sandra.bival@kbc-zagreb.hr (S.B.); \\ eva.pavic@kbc-zagreb.hr (E.P.) \\ 3 Department of Organization and Consumption Economics, Faculty of Human Nutrition and Consumer \\ Sciences, Warsaw University of Life Sciences (WULS-SGGW), 159c Nowoursynowska Str., \\ 02-776 Warsaw, Poland; dominika_guzek@sggw.pl \\ 4 Department of Internal Medicine, University Hospital Centre, 12 Kišpatićeva Str., 10-000 Zagreb, Croatia; \\ zlatko.giljevic@kbc-zagreb.hr \\ 5 School of Medicine, Department of Internal Medicine, University of Zagreb, 3 Šalata Str., \\ 10-000 Zagreb, Croatia \\ * Correspondence: dominika_glabska@sggw.pl; Tel.: +48-22-59-371-26
}

Received: 4 August 2019; Accepted: 13 September 2019; Published: 17 September 2019

\begin{abstract}
In Poland and Croatia, similarly as for a number of European countries, anemia and osteoporosis are common diet-related diseases in women, while for both the proper nutritional behaviors and preventive education are crucial. However, for the proper nutritional education there are some barriers, including those associated with an educator, his own nutritional behaviors and beliefs. The aim of the study was to assess the dietary health risk factors for women in the Polish and Croatian population based on the nutritional behaviors of junior health professionals. The study was conducted in Polish $(n=70)$ and Croatian $(n=80)$ female students of the faculties associated with public health at the universities in capital cities. Their diets were assessed based on 3-day dietary records. Nutritional value and consumption of food products, as well as the dietary risk factors for anemia and osteoporosis, were compared. While assessing the risk factors for anemia, in the Polish group, the higher intake of iron and folate, as well as vitamin $B_{12}$ per $1000 \mathrm{kcal}$, was observed; and for folate, the higher frequency of inadequate intake was stated for Croatian women. While assessing the risk factors for osteoporosis, in the Polish group, compared with the Croatian, the higher intake of calcium per $1000 \mathrm{kcal}$ was observed, but for vitamin D, there were no differences. Differences of the intake between the Polish and the Croatian group of junior health professionals may result in various dietary health risks for women. Based on the assessment of dietary intake, for anemia, compared to Polish women, a higher risk may be indicated for Croatian women, but for osteoporosis, similar risks may be indicated for Polish and Croatian women. Therefore, for public health, adequate nutritional education of junior health professionals is necessary.
\end{abstract}

Keywords: diet; nutrition; intake; public health; health professionals; dietary risk

\section{Introduction}

According to the World Health Organization (WHO), a number of women die because of noncommunicable diseases before they reach the age of 70-it was estimated that there were 4.7 million 
of such deaths in 2012 [1]. Women also generally suffer due to decreased quality of life and well-being - this indicates that there is a need to work toward improving the health and well-being of women and girls, beyond maternal and child care [2].

A number of noncommunicable diseases are diet-related; hence, nutritional education is crucial to prevent these diseases. However, it has been observed that it is not enough for nutritional educators to have the proper qualifications, including the right knowledge and skills, to affect change- - the educators' own beliefs may influence health education [3]. The nutritional educators' own nutritional behaviors and beliefs may influence the information that is presented to patients and may interfere with the process of imparting knowledge [4]. At the same time, nutritional educators should follow diet recommendations; previous studies have shown that if educators had excessive body mass, it negatively affected the perception of their credibility, level of trust, and inclination of the patient to follow their advice [5].

Providing dietary recommendations is a serious problem as, generally, physicians do not even engage in nutritional counseling [6], while the other nutritional educators often do not have adequate knowledge and skills [7-9]; sometimes, even dietitians do not have it [10-12]. Although some studies indicate that dietitians follow their own advice of maintaining a well-balanced diet [13], others conclude that the nutritional behaviors of dietitians generally are not in agreement with their own recommendations; both dietitians and other nutritional educators consume inadequate amounts of fruits and vegetables [14-16] and fish [14,17] — they also consume sweets [17] and fast food meals [16] too often. This data corresponds to the excessive body mass commonly reported for physicians [18], nurses [19], educators [20], and also for dietitians [21]. Moreover, malnutrition has also been reported in dietitians [15] and the lower body mass is often related with symptoms of orthorexia nervosa [22]. The improper nutritional behaviors of health professionals are associated with a diet that is characterized by inadequate intake of fiber [23,24], calcium [23,25], iron [19,23], potassium [23], vitamin A [19], vitamin D [23], riboflavin [19], folate [19,23], and vitamin $B_{12}$ [19].

Taking all this information into account, two major problems can be highlighted. These problems are related with educators providing misleading information to their patients based on their own beliefs, which results in the patients maintaining an unhealthy diet; in other cases, patients do not follow the nutritional educators' recommendations because of loss of trust and confidence in them. Consequently, it may be assumed that proper nutritional behaviors of nutritional educators may be crucial for effective education; if the educators do not follow proper nutritional behavior, they may directly generate health-related dietary risk factors for patients.

Anemia [26] and osteoporosis [27] are the diet-related diseases typical for women. The two conditions may be associated, and when they occur at the same time, they cause even more serious reduction of the quality of life in the affected individuals [28].

The frequency of decreased blood hemoglobin concentration $(<120 \mathrm{~g} / \mathrm{L})$, interpreted as the occurrence of anemia according to the WHO [29] definition, is high even for the developed regions of the world, especially for women [30]. According to WHO estimations, the prevalence of anemia in nonpregnant women aged $15-49$ is $22.5 \%$ (ranging from 16.4 to $30.1 \%$ ) in the European region, being $23 \%$ in Poland and $24 \%$ in Croatia; for pregnant women, the frequency is even higher [31]. The primary diet-related reasons for anemia are deficiencies of iron [32], folate [33], and vitamin $\mathrm{B}_{12}$ [34], although WHO indicated iron deficiency as the most prominent contributor [35].

The frequency of osteoporosis, according to the statistics of the International Osteoporosis Foundation (IOF) [36], for European countries is also high, as for women aged over 50 (the group especially prone to osteoporosis), its occurrence is $21-24 \%$, contributing to an estimated lifetime risk of hip fracture of $22.8 \%$. In this age group, the frequency of osteoporosis in Poland is also estimated at about $20 \%$, contributing to hip fractures in $3 \%$ of the female population [37]. As was observed by Cvijetić et al. [38], for Croatia, there are no detailed osteoporosis statistics; but it is estimated that 39\% of individuals aged over 60 have osteoporosis, with 95\% of them being women [39]. At the same time, based on the data for Zagreb (the capital city of Croatia), the frequency of vertebral fractures for women 
in the group aged over 50 was estimated as 9.7\% [40]. As calcium intake is directly associated with bone mass, it is the primary diet-related influencing factor [41]; however, vitamin $\mathrm{D}$ is also a factor that contributes to better calcium absorption and bone mineralization, and thus bone mineral density [42].

In this study, our aim was to assess the dietary health risk factors for women in the Polish and Croatian population based on the nutritional behaviors of junior health professionals. Taking into account the comprehensive quality of diet, we planned to assess not only the daily intake, but also the proportions of macronutrients (the share of energy contribution), as well as the nutrient density of diet [43] (expressed as daily intake recalculated per $1000 \mathrm{kcal}$ ). Moreover, we also included the assessment of food products intake and food products intake recalculated per $1000 \mathrm{kcal}$. In order to include issues related to the environmental effects of food production, we decided to assess, under food products intake, animal-derived products separately; under the intake of protein, we decided to assess animal and plant protein separately. Western populations generally have too high total protein intake [44]; it has also been observed that environmental impact reduction is proportional to the animal products share reduction [45]. This study was planned to be conducted by assessing the dietary risk factors for anemia and osteoporosis, which are the most common diet-related diseases for women and may influence the social sustainability level in populations.

\section{Materials and Methods}

\subsection{Ethical Statement}

The study was conducted according to the guidelines of the Declaration of Helsinki. It was approved by the Bioethical Commission of the National Food and Nutrition Institute in Warsaw (No. 0701/2015). All the participants provided their informed consent to participate in the study.

\subsection{Studied Group}

The study was conducted among two groups of junior health professionals who were students of faculties associated with public health at universities located in capital cities. It was decided to recruit students that in the future should be characterized by a general nutritional knowledge only, and not specialists in dietetics or medicine. Hence, students of dietary and medical courses were not included; only those who planned to become general nutritional specialists conducting group nutritional education in and outside of hospitals were recruited. For Poland, it was the Warsaw University of Life Sciences (WULS-SGGW) in Warsaw, whereas for Croatia it was the University of Applied Health Sciences (Zdravstveno Veleučilište u Zagrebu-ZVU) in Zagreb.

The students were invited to participate in the study in the semester when they had their dietitian classes to assess nutritional behaviors of students characterized by a similar level of nutritional knowledge. The inclusion criteria were as follows:

- female;

- $\quad$ aged 19-25;

- living in the capital city or around it;

- $\quad$ student of faculty associated with health science and promotion; and

- providing written informed consent to participate.

The exclusion criteria were as follows:

- being pregnant or breastfeeding;

- any chronic diet-related disease diagnosed;

- currently trying to lose weight; and

- following any special diet. 
In the indicated universities, based on the indicated inclusion and exclusion criteria, two independent groups of participants were recruited: 70 young women in the Polish group and 80 young women in the Croatian group.

\subsection{Assessment of the Diet}

The assessment of the diet was based on a 3-day dietary record, according to widely applicable rules [46]. The dietary assessment was conducted by respondents during three random and nonconsecutive days, which were commanded to be typical and two of them were to be weekdays and one weekend day. The study's participants had a structured form to be completed with the information about consumed meals: the place where they were consumed, consumption time, and detailed description (products included, applied culinary and cooking techniques, serving size). The serving size was to be indicated either in grams (if they possessed a kitchen scale or consumed packed products with such information on the packaging) or in a descriptive manner (as a standard household measures). The respondents were instructed about the need to note all the products and all the beverages in a scrupulous manner. Moreover, they were informed about the need to not change their typical dietary habits because of keeping the dietary record.

Both groups of respondents were given identical forms (in their native language, either Polish or Croatian) and identical instructions to conduct the 3-day dietary record. The instructions were translated into Polish/Croatian by native Polish/Croatian speakers who were dietitians to obtain an accurate description of necessary issues, including some examples as to how to keep the dietary record.

Subsequently, to obtain a comparable analysis of the diet, independent from the applied databases, the same tables of nutritional value of food products and dishes were applied for both groups. The Polish tables were selected; therefore, the dietary records obtained for the Croatian group were translated to Polish, as in the previously conducted own study [47]. The translation was independently conducted in two stages: two English-speaking Croatian dietitians translated them from Croatian to English (while describing the specific dishes and providing the photographs of typical Croatian products and information about recipes, if needed), and afterwards two English-speaking Polish dietitians independently translated Croatian dietary records from English to Polish (verifying all the doubts with Croatian dietitians, if needed). The applied procedure resulted in obtaining both Polish and Croatian dietary records translated into Polish to be analyzed using the same database (the Polish one).

The Polish 3-day dietary records and the Croatian ones, translated into Polish (in a 2-step process via English), were afterwards analyzed in four ways as follows:

- The typical nutritional value of the diet, which was assessed for the energy value of the diet and the following nutrients: total protein, animal protein, plant protein, protein as a share of energy value, fat, saturated fatty acids, monounsaturated fatty acids, polyunsaturated fatty acids, cholesterol, fat as a share of energy value, total carbohydrates, sucrose, lactose, starch, fiber, carbohydrate as a share of energy value (macronutrients), sodium, potassium, calcium, phosphorus, iron, magnesium, zinc, copper, manganese, iodine (minerals), thiamine, riboflavin, niacin, vitamin $\mathrm{B}_{6}$, folate, vitamin $B_{12}$, vitamin $A$, vitamin $E$, vitamin $C$, vitamin $D$ (vitamins). The nutritional value was assessed for a mean daily intake and was calculated using the tables of nutritional value of food products and dishes by the Polish National Food and Nutrition Institute in Warsaw [48] and the Polish dietitian software Energia 4.1.;

- The typical nutritional value of the diet recalculated per $1000 \mathrm{kcal}$ of the diet, which was assessed for the nutrients, independently recalculated to enable reliable comparison;

- The typical consumption of food products, which was assessed for the following groups: milk and dairy beverages, cottage cheese, hard cheese, eggs, meat, cold cuts, fish and fish products, butter, sour cream (animal-derived products), vegetables, legumes, fruits, potatoes, bread, other cereal products, oil, margarine, nuts, mushrooms, sugar, jam and honey, chocolate sweets, cakes and cookies, alcoholic beverages, sweetened beverages (other food products). The consumed dishes 
were deconstructed into food products, and they were then divided into listed groups, which are commonly applied for assessing the intake of food products [49];

- The typical consumption of food products recalculated per $1000 \mathrm{kcal}$ of the diet, which was assessed for the food product groups, independently recalculated to enable reliable comparison.

While assessing sodium intake, the salt added to dishes was not calculated, but only that naturally present in food products or in processed food products. This is because, in general, dietary intake assessment is not a recommended method to analyze sodium intake; the 24-hour urine collection is the 'gold standard' for this assessment [50] and is commonly applied [51]. Moreover, dietary intake assessment methods usually do not capture the amount of sodium obtained from salt added to dishes consumed [52]. This is because, in western countries, excessive sodium intake is common; in practice, the risk of inadequate intake does not exist [53].

Subsequently, the groups were compared for the obtained nutritional value and the intake of food products. Moreover, the dietary health risk factors were specified for each population, and the most common ones for young women's diet-related health risks were selected and the related nutrients were analyzed as follows: anemia (iron, folate, and vitamin $\mathrm{B}_{12}$ ) [54] and osteoporosis (calcium and vitamin D) [55]. Vitamin D was included in the analysis in spite of the fact that it is mainly generated in skin after sunshine exposure [56]. However, inadequate exposure that is commonly stated results in need for at least adequate dietary intake [57]. Combined inadequate sunshine exposure and inadequate intake result in vitamin D deficiency [58] that is observed both for Poland [59] and Croatia [60].

The intakes of indicated nutrients in groups were compared with the recommended intake values, as specified by National Institutes of Health [61], while the Estimated Average Requirement (EAR) values were selected as a reference to estimate the prevalence of inadequate intake [62]. We applied the following reference values: calcium $(800 \mathrm{mg})$, iron $(8.1 \mathrm{mg})$, folate $(320 \mu \mathrm{g})$, vitamin $\mathrm{B}_{12}(2 \mu \mathrm{g})$, and vitamin D $(10 \mu \mathrm{g})[61]$.

\subsection{Statistical Analysis}

The distribution was verified using the Shapiro-Wilk test. Afterwards, the t-Student test (for parametric distributions) and the U Mann-Whitney test (for nonparametric distributions) were applied for comparison of the typical intakes. At the same time, the chi ${ }^{2}$ test was applied for comparison of the prevalence of inadequate intake.

The statistical analysis was conducted for the accepted level of significance of $p \leq 0.05$ and while using Statistica, version 8.0 (Statsoft Inc., Tulsa, OK, USA).

\section{Results}

Comparison of energy value and macronutrients intake in groups of junior health professionals from Poland and Croatia is presented in Table 1. In the analyzed group, Polish women, while compared with Croatian ones, were characterized by a higher protein $(p=0.0001)$, but lower carbohydrates share in energy value of the diet $(p=0.0068)$. At the same time, they were characterized by lower intake of sucrose $(p=0.0109)$ and starch $(p=0.0098)$, but higher intake of fiber $(p=0.0002)$.

Comparison of macronutrients intake per $1000 \mathrm{kcal}$ in groups of junior health professionals from Poland and Croatia is presented in Table 2. In the analyzed group, Polish women, while compared with Croatian ones, were characterized by a higher total protein $(p=0.0001)$, animal protein $(p=0.0190)$, plant protein $(p=0.0270)$, polyunsaturated fatty acids $(p=0.0071)$, lactose $(p=0.0205)$ and fiber intake $(p<0.0001)$. At the same time, they were characterized by lower intake of sucrose $(p=0.0098)$ and $\operatorname{starch}(p=0.0015)$. 
Table 1. Comparison of energy value and macronutrients intake in groups of junior health professionals from Poland and Croatia.

\begin{tabular}{|c|c|c|c|c|c|}
\hline & \multicolumn{2}{|c|}{ Polish Group } & \multicolumn{2}{|c|}{ Croatian Group } & \multirow{2}{*}{$p^{* *}$} \\
\hline & Mean \pm SD & Median (Range) & Mean \pm SD & Median (Range) & \\
\hline Energy value (kcal) & $1492.3 \pm 420.7$ & $1415.4 *(756.8-2870.0)$ & $1569.0 \pm 561.0$ & $1466.0 *(718.3-3743.9)$ & 0.4115 \\
\hline Animal protein $(\mathrm{g})$ & $53.5 \pm 22.4$ & $51.7(0.2-124.1)$ & $50.3 \pm 20.5$ & $49.1(9.8-103.2)$ & 0.3465 \\
\hline Plant protein $(\mathrm{g})$ & $26.0 \pm 11.8$ & $23.4 *(7.1-65.7)$ & $23.4 \pm 9.1$ & $22.2 *(7.1-60.5)$ & 0.4741 \\
\hline Protein (\% EV) & $22.0 \pm 5.0$ & $22.0(5-33)$ & $13.0 \pm 5.0$ & $12.0 *(5-26)$ & 0.0001 \\
\hline Monounsaturated fatty acids (g) & $22.4 \pm 10.2$ & $21.3 *(4.8-58.6)$ & $23.2 \pm 11.6$ & $21.5 *(6.7-64.6)$ & 0.8168 \\
\hline Polyunsaturated fatty acids (g) & $10.6 \pm 5.9$ & $8.9 *(2.3-30.5)$ & $8.9 \pm 4.9$ & $8.1 *(2.3-26.0)$ & 0.0773 \\
\hline Cholesterol (mg) & $316.9 \pm 240.1$ & $230.0 *(28.0-878.5)$ & $266.6 \pm 138.0$ & $227.4 *(26.9-609.1)$ & 0.8832 \\
\hline Fat $(\%$ of EV) & $34.0 \pm 8.0$ & $34.0(15-50)$ & $33.0 \pm 8.0$ & $33.0(14-56)$ & 0.5963 \\
\hline Total carbohydrates $(\mathrm{g})$ & $190.2 \pm 65.3$ & $180.8 *(81.5-386.9)$ & $204.7 \pm 81.7$ & $193.3 *(52.2-501.4)$ & 0.1449 \\
\hline Carbohydrate (\% EV) & $44.0 \pm 10.0$ & $44.0(35-67)$ & $47.0 \pm 9.0$ & $47.0 *(16-71)$ & 0.0068 \\
\hline
\end{tabular}

EV-Energy Value; * nonparametric distribution (verified using the Shapiro-Wilk test; $p<0.05$ ); ${ }^{* *}$ compared using the t-Student test (for parametric distributions) or the U Mann-Whitney test (for nonparametric distributions).

Table 2. Comparison of macronutrients intake per $1000 \mathrm{kcal}$ in groups of junior health professionals from Poland and Croatia.

\begin{tabular}{|c|c|c|c|c|c|}
\hline & \multicolumn{2}{|c|}{ Polish Group } & \multicolumn{2}{|c|}{ Croatian Group } & \multirow{2}{*}{$p^{* *}$} \\
\hline & Mean \pm SD & Median (Range) & Mean \pm SD & Median (Range) & \\
\hline Total protein $(\mathrm{g})$ & $54.3 \pm 12.7$ & $55.5(12.5-83.2)$ & $47.9 \pm 10.7$ & $46.8 *(29.7-79.3)$ & 0.0001 \\
\hline Animal protein $(\mathrm{g})$ & $36.9 \pm 14.4$ & $36.2(0.2-67.4)$ & $32.7 \pm 11.7$ & $29.9(13.5-65.5)$ & 0.0190 \\
\hline Plant protein $(\mathrm{g})$ & $17.4 \pm 6.2$ & $16.7 *(5.1-39.8)$ & $15.2 \pm 4.5$ & $14.5(6.4-35.9)$ & 0.0270 \\
\hline Total fat $(\mathrm{g})$ & $37.4 \pm 8.7$ & $37.3(17.1-55.8)$ & $36.6 \pm 8.6$ & $36.8 *(15.1-62.1)$ & 0.3842 \\
\hline Saturated fatty acids (g) & $12.3 \pm 4.3$ & $11.78(2.5-23.9)$ & $13.4 \pm 4.2$ & $12.9 *(5.8-24.4)$ & 0.1338 \\
\hline Monounsaturated fatty acids (g) & $15.0 \pm 5.3$ & $14.4(5.3-26.9)$ & $14.6 \pm 4.4$ & $14.4 *(4.4-29.8)$ & 0.6539 \\
\hline Polyunsaturated fatty acids (g) & $7.1 \pm 3.2$ & $6.4 *(1.5-13.9)$ & $5.6 \pm 2.2$ & $5.3 *(2.0-14.1)$ & 0.0071 \\
\hline Cholesterol (mg) & $216.5 \pm 165.1$ & $163.1 *(25.2-597.8)$ & $171.8 \pm 78.8$ & $162.5 *(37.4-419.0)$ & 0.8773 \\
\hline Total carbohydrates (g) & $127.6 \pm 25.0$ & $125.8(71.5-186.0)$ & $130.5 \pm 23.0$ & $132.9 *(46.9-198.4)$ & 0.2237 \\
\hline Sucrose $(\mathrm{g})$ & $18.1 \pm 12.0$ & $14.9 *(4.3-75.5)$ & $20.9 \pm 10.2$ & $18.6 *(65.8-1.5)$ & 0.0098 \\
\hline Lactose (g) & $9.4 \pm 5.9$ & $8.8 *(0.0-37.6)$ & $7.5 \pm 3.8$ & $7.6 *(0.0-23.4)$ & 0.0205 \\
\hline Starch $(\mathrm{g})$ & $60.4 \pm 24.6$ & $60.2 *(15.7-128.2)$ & $69.1 \pm 16.9$ & $72.5 *(27.1-109.8)$ & 0.0015 \\
\hline Fiber $(\mathrm{g})$ & $17.3 \pm 7.1$ & $16.6 *(5.6-40.7)$ & $12.5 \pm 4.4$ & $11.9 *(6.2-27.4)$ & $<0.0001$ \\
\hline
\end{tabular}

${ }^{*}$ Nonparametric distribution (verified using the Shapiro-Wilk test; $p<0.05$ ); ${ }^{* *}$ compared using the $\mathrm{t}$-Student test (for parametric distributions) or the U Mann-Whitney test (for nonparametric distributions).

Comparison of minerals intake in groups of junior health professionals from Poland and Croatia is presented in Table 3. In the analyzed group, Polish women, while compared with Croatian ones, were characterized by a higher potassium $(p=0.0059)$, phosphorus $(p=0.0002)$, iron $(p=0.0062)$, magnesium $(p<0.0001)$, zinc $(p=0.0086)$, copper $(p=0.0001)$, manganese $(p=0.0166)$, and iodine intake $(p=0.0001)$.

Comparison of minerals intake per $1000 \mathrm{kcal}$ in groups of junior health professionals from Poland and Croatia is presented in Table 4. In the analyzed group, Polish women, while compared with Croatian ones, were characterized by a higher potassium $(p=0.0007)$, calcium $(p=0.0111)$, phosphorus $(p<0.0001)$, iron $(p<0.0001)$, magnesium $(p<0.0001)$, zinc $(p<0.0001)$, copper $(p<0.0001)$, manganese $(p=0.0015)$, and iodine intake $(p<0.0001)$.

Comparison of vitamins intake in groups of junior health professionals from Poland and Croatia is presented in Table 5. In the analyzed group, Polish women, while compared with Croatian ones, were characterized by a higher riboflavin $(p=0.0063)$, vitamin $\mathrm{B}_{6}(p=0.0040)$, folate $(p=0.0027)$, vitamin $\mathrm{A}(p=0.0008)$, and vitamin $\mathrm{E}$ intake $(p=0.0119)$. At the same time, they were characterized by lower intake of niacin $(p=0.0043)$. 
Table 3. Comparison of minerals intake in groups of junior health professionals from Poland and Croatia.

\begin{tabular}{cccccc}
\hline & \multicolumn{2}{c}{ Polish Group } & \multicolumn{2}{c}{ Croatian Group } & \multirow{2}{*}{$p^{* *}$} \\
\cline { 2 - 5 } & Mean \pm SD & Median (Range) & Mean \pm SD & Median (Range) & \\
\hline Sodium (mg) & $1229.6 \pm 662.5$ & $1087.0 *(289.9-3179.8)$ & $1342.5 \pm 723.1$ & $1218.9 *(125.7-3589.7)$ & 0.3883 \\
Potassium (mg) & $3242.4 \pm 1003.1$ & $3239.8^{*}(1215.9-5279.2)$ & $2812.1 \pm 979.3$ & $2602.2(1327.2-7484.2)$ & 0.0059 \\
Calcium $(\mathrm{mg})$ & $751.7 \pm 294.8$ & $746.8(194.2-1640.2)$ & $700.1 \pm 315.7$ & $647.3 *(168.5-1469.0)$ & 0.2324 \\
Phosphorus (mg) & $1480.9 \pm 419.6$ & $1473.6(575.9-3010.1)$ & $1257.2 \pm 422.5$ & $1163.2 *(588.3-3273.0)$ & 0.0002 \\
Iron (m) & $12.1 \pm 5.2$ & $10.9^{*}(4.3-25.0)$ & $10.1 \pm 4.1$ & $9.2 *(4.7-31.1)$ & 0.0062 \\
Magnesium (mg) & $360.1 \pm 128.9$ & $347.0^{*}(154.1-738.3)$ & $280.8 \pm 134.0$ & $260.2 *(129.4-958.6)$ & $<0.0001$ \\
Zinc (mg) & $10.3 \pm 3.6$ & $9.7 *(3.7-22.0)$ & $8.9 \pm 3.2$ & $8.4 *(4.2-21.3)$ & 0.0086 \\
Copper (mg) & $1.4 \pm 0.6$ & $1.2 *(0.5-3.4)$ & $1.0 \pm 0.4$ & $1.0 *(0.5-2.7)$ & 0.0001 \\
Manganese $(\mathrm{mg})$ & $4.7 \pm 1.9$ & $4.3^{*}(1.5-10.3)$ & $4.0 \pm 2.4$ & $3.8^{*}(0.8-15.5)$ & 0.0166 \\
Iodine $(\mathrm{mg})$ & $71.4 \pm 62.2$ & $47.6^{*}(3.4-302.2)$ & $41.4 \pm 32.1$ & $31.6 *(6.3-193.6)$ & 0.0001 \\
\hline
\end{tabular}

${ }^{*}$ Nonparametric distribution (verified using the Shapiro-Wilk test; $p<0.05$ ); ${ }^{* *}$ compared using the $\mathrm{t}$-Student test

(for parametric distributions) or the U Mann-Whitney test (for nonparametric distributions).

Table 4. Comparison of minerals intake per $1000 \mathrm{kcal}$ in groups of junior health professionals from Poland and Croatia.

\begin{tabular}{cccccc}
\hline & \multicolumn{2}{c}{ Polish Group } & \multicolumn{2}{c}{ Croatian Group } & \multirow{2}{*}{$\boldsymbol{p}^{* *}$} \\
\cline { 2 - 5 } & Mean \pm SD & Median (Range) & Mean \pm SD & Median (Range) & \\
\hline Sodium (mg) & $823.4 \pm 370.4$ & $745.5^{*}(238.1-1810.1)$ & $834.9 \pm 299.3$ & $819.3(175.0-1483.1)$ & 0.6110 \\
Potassium $(\mathrm{mg})$ & $2241.4 \pm 701.1$ & $3229.8^{*}(1220.2-3960.3)$ & $1850.0 \pm 514.3$ & $1815.3 *(928.2-3314.3)$ & 0.0007 \\
Calcium (mg) & $525.5 \pm 209.5$ & $503.8(123.5-1161.6)$ & $440.3 \pm 133.5$ & $437.3(151.3-743.2)$ & 0.0111 \\
Phosphorus (mg) & $1016.4 \pm 236.5$ & $1007.0(366.3-1676.0)$ & $811.2 \pm 148.2$ & $802.5^{*}(569.4-1312.3)$ & $<0.0001$ \\
Iron (mg) & $8.4 \pm 3.7$ & $7.4 *(2.9-26.1)$ & 6.451 .6 & $6.1 *(4.2-12.0)$ & $<0.0001$ \\
Magnesium (mg) & $249.5 \pm 92.6$ & $224.4^{*}(111.1-653.0)$ & $182.3 \pm 48.6$ & $176.7^{*}(106.9-332.2)$ & $<0.0001$ \\
Zinc (mg) & $7.0 \pm 1.9$ & $6.9(2.4-12.0)$ & $5.7 \pm 1.2$ & $5.7^{*}(3.6-12.0)$ & $<0.0001$ \\
Copper $(\mathrm{mg})$ & $1.0 \pm 0.4$ & $0.9^{*}(0.4-2.0)$ & $0.7 \pm 0.2$ & $0.7 *(0.4-1.3)$ & $<0.0001$ \\
Manganese $(\mathrm{mg})$ & $3.2 \pm 1.3$ & $3.0^{*}(1.1-7.3)$ & $2.6 \pm 1.0$ & $2.5(0.8-5.4)$ & 0.0015 \\
Iodine $(\mathrm{mg})$ & $49.2 \pm 2.9$ & $36.2^{*}(2.4-218.2)$ & $27.9 \pm 25.0$ & $19.2 *(3.0-126.0)$ & $<0.0001$ \\
\hline
\end{tabular}

${ }^{*}$ Nonparametric distribution (verified using the Shapiro-Wilk test; $p<0.05$ ); ${ }^{* *}$ compared using the t-Student test (for parametric distributions) or the U Mann-Whitney test (for nonparametric distributions).

Table 5. Comparison of vitamins intake in groups of junior health professionals from Poland and Croatia.

\begin{tabular}{|c|c|c|c|c|c|}
\hline & \multicolumn{2}{|c|}{ Polish Group } & \multicolumn{2}{|c|}{ Croatian Group } & \multirow{2}{*}{$p^{* *}$} \\
\hline & Mean \pm SD & Median (Range) & Mean \pm SD & Median (Range) & \\
\hline Thiamine (mg) & $1.1 \pm 0.4$ & $1.1 *(0.4-2.9)$ & $1.2 \pm 0.5$ & $1.12 *(0.5-3.0)$ & 0.8212 \\
\hline Riboflavin (mg) & $1.8 \pm 0.6$ & $1.8(0.4-3.2)$ & $1.6 \pm 0.6$ & $1.5 *(0.7-3.4)$ & 0.0063 \\
\hline Niacin (mg) & $14.9 \pm 6.5$ & $13.9 *(4.2-38.6)$ & $17.82 \pm 8.2$ & $16.8 *(5.0-50.1)$ & 0.0043 \\
\hline Vitamin $B_{6}(\mathrm{mg})$ & $2.2 \pm 0.7$ & $2.0(0.6-4.1)$ & $1.9 \pm 0.8$ & $1.7 *(0.9-5.4)$ & 0.0040 \\
\hline Folate (ug) & $380.7 \pm 157.9$ & $370.9(124.0-776.6)$ & $310.6 \pm 137.9$ & $284.0 *(143.7-891.8)$ & 0.0027 \\
\hline Vitamin $B_{12}(u g)$ & $4.2 \pm 2.4$ & $3.8 *(0.0-10.3)$ & $3.6 \pm 2.1$ & $3.1 *(0.6-11.9)$ & 0.0712 \\
\hline Vitamin A (ug) & $1700.9 \pm 1599.9$ & $1126.7 *(176.6-9278.2)$ & $939.1 \pm 691.8$ & $792.2 *(225.4-3473.4)$ & 0.0008 \\
\hline Vitamin E (mg) & $11.9 \pm 6.6$ & $10.6(2.3-35.7)$ & $9.3 \pm 4.9$ & $8.4 *(2.6-26.8)$ & 0.0119 \\
\hline Vitamin C (mg) & $156.2 \pm 114.3$ & $126.5 *(6.2-490.5)$ & $130.7 \pm 93.5$ & $101.6 *(18.4-229.9)$ & 0.2915 \\
\hline Vitamin D (ug) & $3.1 \pm 4.0$ & $1.8 *(0.0-26.2)$ & $2.4 \pm 2.2$ & $1.9 *(0.1-12.4)$ & 0.6814 \\
\hline
\end{tabular}

${ }^{*}$ Nonparametric distribution (verified using the Shapiro-Wilk test; $p<0.05$ ); ${ }^{* *}$ compared using the $\mathrm{t}$-Student test

(for parametric distributions) or the U Mann-Whitney test (for nonparametric distributions).

Comparison of vitamins intake per $1000 \mathrm{kcal}$ in groups of junior health professionals from Poland and Croatia is presented in Table 6 . In the analyzed group, Polish women, while compared with Croatian ones, were characterized by a higher riboflavin $(p<0.0001)$, vitamin $\mathrm{B}_{6}(p=0.0011)$, folate $(p=0.0006)$, vitamin $B_{12}(p=0.0074)$, vitamin $A(p=0.0004)$, and vitamin $\mathrm{E}$ intake $(p=0.0015)$. At the same time, they were characterized by lower intake of niacin $(p=0.0176)$.

Comparison of animal-derived products intake in groups of junior health professionals from Poland and Croatia is presented in Table 7 . In the analyzed group, Polish women, while compared 
with Croatian ones, were characterized by a higher cottage cheese $(p=0.0062)$, but lower cold cuts intake $(p=0.0023)$.

Comparison of animal-derived products intake per $1000 \mathrm{kcal}$ in groups of junior health professionals from Poland and Croatia is presented in Table 8. In the analyzed group, Polish women, while compared with Croatian ones, were characterized by a higher cottage cheese $(p=0.0084)$, but lower cold cuts intake ( $p=0.0035)$.

Table 6. Comparison of vitamins intake per $1000 \mathrm{kcal}$ in groups of junior health professionals from Poland and Croatia.

\begin{tabular}{cccccc}
\hline & \multicolumn{2}{c}{ Polish Group } & \multicolumn{2}{c}{ Croatian Group } & \multirow{2}{*}{$\boldsymbol{p}^{* *}$} \\
\cline { 2 - 5 } & Mean \pm SD & Median (Range) & Mean \pm SD & Median (Range) & \\
\hline Thiamine (mg) & $0.8 \pm 0.2$ & $0.8(0.3-1.7)$ & $0.8 \pm 0.2$ & $0.8(0.4-1.3)$ & 0.7920 \\
Riboflavin (mg) & $1.3 \pm 0.4$ & $1.2(0.3-2.1)$ & $1.0 \pm 0.2$ & $1.0^{*}(0.6-1.6)$ & $<0.0001$ \\
Niacin (mg) & $10.2 \pm 4.0$ & $9.4(4.5-20.9)$ & $11.7 \pm 4.3$ & $11.3 *(4.1-23.2)$ & 0.0176 \\
Vitamin B $(\mathrm{mg})$ & $1.5 \pm 0.6$ & $1.5^{*}(0.7-3.0)$ & $1.3 \pm 0.4$ & $1.2 *(0.6-2.5)$ & 0.0011 \\
Folate (ug) & $268.8 \pm 133.3$ & $235.5^{*}(83.1-808.0)$ & $204.8 \pm 73.8$ & $187.1^{*}(105.3-497.8)$ & 0.0006 \\
Vitamin B 12 (ug) & $2.9 \pm 1.6$ & $2.6^{*}(0.0-7.5)$ & $2.4 \pm 1.4$ & $1.9 *(0.8-8.6)$ & 0.0074 \\
Vitamin A (ug) & $1212.9 \pm 1191.6$ & $724.3^{*}(121.1-6699.8)$ & $200.3 \pm 77.4$ & $196.4^{*}(16.3-424.3)$ & 0.0004 \\
Vitamin E (mg) & $8.1 \pm 3.9$ & $7.8(1.4-17.2)$ & $6.0 \pm 2.4$ & $5.4 *(2.7-13.0)$ & 0.0015 \\
Vitamin C (mg) & $156.2 \pm 114.3$ & $126.5^{*}(6.2-490.5)$ & $88.2 \pm 60.7$ & $69.4 *(8.1-352.0)$ & 0.1836 \\
Vitamin D (ug) & $2.1 \pm 2.8$ & $1.3 *(0.0-17.5)$ & $1.6 \pm 1.3$ & $1.2 *(0.3-7.3)$ & 0.7204 \\
\hline
\end{tabular}

${ }^{*}$ Nonparametric distribution (verified using the Shapiro-Wilk test; $p<0.05$ ); ${ }^{* *}$ compared using the t-Student test (for parametric distributions) or the U Mann-Whitney test (for nonparametric distributions).

Table 7. Comparison of animal-derived products intake in groups of junior health professionals from Poland and Croatia.

\begin{tabular}{cccccc}
\hline & \multicolumn{2}{c}{ Polish Group } & \multicolumn{2}{c}{ Croatian Group } & \multirow{2}{*}{$p^{* *}$} \\
\cline { 2 - 4 } & Mean \pm SD & Median (Range) & Mean \pm SD & Median (Range) & \\
\hline Milk, dairy beverages (g) & $202.2 \pm 138.6$ & $200.0^{*}(0-550)$ & $201.0 \pm 130.2$ & $168.5^{*}(0-550)$ & 0.8966 \\
Cottage cheese (g) & $63.5 \pm 89.4$ & $33.0^{*}(0-500)$ & $20.0 \pm 30.0$ & $0.0^{*}(0-134)$ & 0.0062 \\
Hard cheese (g) & $9.6 \pm 15.8$ & $0.0^{*}(0-55)$ & $12.5 \pm 20.1$ & $3.0 *(0-106)$ & 0.1786 \\
Eggs (g) & $46.8 \pm 60.5$ & $0.0^{*}(0-200)$ & $26.6 \pm 30.2$ & $17.0^{*}(0-110)$ & 0.4137 \\
Meat (g) & $79.4 \pm 70.2$ & $100.0^{*}(0-300)$ & $99.0 \pm 53.2$ & $98.5^{*}(0-224)$ & 0.0952 \\
Cold cuts (g) & $7.6 \pm 18.5$ & $0.0^{*}(0-90)$ & $19.8 \pm 31.8$ & $1.0^{*}(0-134)$ & 0.0023 \\
Fish and fish products (g) & $39.4 \pm 60.5$ & $0.0^{*}(0-233)$ & $29.5 \pm 40.8$ & $13.0^{*}(0-167)$ & 0.6745 \\
Butter (g) & $3.3 \pm 7.1$ & $0.0^{*}(0-30)$ & $0.9 \pm 2.1$ & $0.0^{*}(0-10)$ & 0.5429 \\
Sour cream (g) & $2.6 \pm 9.9$ & $0.0^{*}(0-60)$ & $2.9 \pm 11.4$ & $0.0 *(0-60)$ & 0.8212 \\
\hline
\end{tabular}

${ }^{*}$ Nonparametric distribution (verified using the Shapiro-Wilk test; $p<0.05$ ); ${ }^{* *}$ compared using the $\mathrm{t}$-Student test

(for parametric distributions) or the U Mann-Whitney test (for nonparametric distributions).

Table 8. Comparison of animal-derived products intake per $1000 \mathrm{kcal}$ in groups of junior health professionals from Poland and Croatia.

\begin{tabular}{cccccc}
\hline & \multicolumn{2}{c}{ Polish Group } & \multicolumn{2}{c}{ Croatian Group } & \multirow{2}{*}{$p^{* *}$} \\
\cline { 2 - 5 } & Mean \pm SD & Median (Range) & Mean \pm SD & Median (Range) & \\
\hline Milk, dairy beverages (g) & $147.3 \pm 117.2$ & $138.8^{*}(0-636.6)$ & $132.3 \pm 87.6$ & $115.5^{*}(0-414.8)$ & 0.5682 \\
Cottage cheese (g) & $45.5 \pm 64.8$ & $22.9^{*}(0-320.9)$ & $15.0 \pm 25.9$ & $0.0^{*}(0-144.7)$ & 0.0084 \\
Hard cheese (g) & $7.0 \pm 12.0$ & $0.0^{*}(0-52.9)$ & $7.5 \pm 11.1$ & $2.0^{*}(0-60.4)$ & 0.2208 \\
Eggs (g) & $32.8 \pm 42.9$ & $0.0^{*}(0-142.1)$ & $17.7 \pm 21.3$ & $11.6^{*}(0-107.5)$ & 0.4300 \\
Meat (g) & $54.8 \pm 47.1$ & $60.3^{*}(0-162.4)$ & $65.6 \pm 24.1$ & $60.1(0-144.4)$ & 0.1162 \\
Cold cuts (g) & $5.3 \pm 12.4$ & $0.0^{*}(0-51.4)$ & $12.5 \pm 22.3$ & $0.6^{*}(0-119.4)$ & 0.0035 \\
Fish and fish products (g) & $26.3 \pm 40.4$ & $0.0^{*}(0-168.3)$ & $21.0 \pm 28.9$ & $8.9^{*}(0-104.6)$ & 0.6071 \\
Butter (g) & $2.2 \pm 4.2$ & $0.0^{*}(0-18.1)$ & $0.6 \pm 1.5$ & $0.0 *(0-9.8)$ & 0.5355 \\
Sour cream (g) & $2.2 \pm 8.3$ & $0.0^{*}(0-48.5)$ & $1.8 \pm 6.7$ & $0.0^{*}(0-35.2)$ & 0.8080 \\
\hline
\end{tabular}

* Nonparametric distribution (verified using the Shapiro-Wilk test; $p<0.05$ ); ${ }^{* *}$ compared using the $\mathrm{t}$-Student test (for parametric distributions) or the U Mann-Whitney test (for nonparametric distributions). 
Comparison of other products intake in groups of junior health professionals from Poland and Croatia is presented in Table 9. In the analyzed group, Polish women, while compared with Croatian ones, were characterized by a higher vegetables $(p=0.0049)$, oil $(p=0.0238)$, nuts $(p=0.0455)$, and jam/honey intake $(p=0.0471)$. At the same time, they were characterized by lower intake of potatoes $(p<0.0001)$, chocolate sweets $(p=0.0042)$, and cakes/cookies $(p=0.0006)$.

Comparison of other products intake per $1000 \mathrm{kcal}$ in groups of junior health professionals from Poland and Croatia is presented in Table 10. In the analyzed group, Polish women, while compared with Croatian ones, were characterized by a higher vegetables $(p=0.0035)$, oil $(p=0.0114)$, nuts $(p=0.0419)$, and jam/honey intake $(p=0.0425)$. At the same time, they were characterized by lower intake of potatoes $(p<0.0001)$, chocolate sweets $(p=0.0041)$, and cakes/cookies $(p=0.0044)$.

Table 9. Comparison of other products intake in groups of junior health professionals from Poland and Croatia.

\begin{tabular}{|c|c|c|c|c|c|}
\hline & \multicolumn{2}{|c|}{ Polish Group } & \multicolumn{2}{|c|}{ Croatian Group } & \multirow{2}{*}{$p^{* *}$} \\
\hline & Mean \pm SD & Median (Range) & Mean \pm SD & Median (Range) & \\
\hline Vegetables (g) & $305.2 \pm 230.9$ & $275 *(0-1000)$ & $205.7 \pm 151.7$ & $160.0 *(13-810)$ & 0.0049 \\
\hline Legumes $(\mathrm{g})$ & $17.5 \pm 69.7$ & $0.0 *(0-550)$ & $6.9 \pm 24.8$ & $0.0 *(0-200)$ & 0.6952 \\
\hline Fruits (g) & $183.8 \pm 119.6$ & $152 *(0-540)$ & $193.7 \pm 145.3$ & $167.0 *(0-800)$ & 0.9970 \\
\hline Potatoes $(\mathrm{g})$ & $31.3 \pm 69.1$ & $0.0 *(0-267)$ & $65.9 \pm 67.5$ & $50.0 *(0-333)$ & $<0.0001$ \\
\hline Bread $(\mathrm{g})$ & $69.9 \pm 63.6$ & $62.0 *(0-210)$ & $72.8 \pm 48.4$ & $65.0 *(0-183)$ & 0.3873 \\
\hline Other cereal products $(\mathrm{g})$ & $79.7 \pm 57.6$ & $66.0 *(0-270)$ & $87.4 \pm 77.8$ & $65.5 *(0-390)$ & 0.9474 \\
\hline Oil (g) & $11.1 \pm 10.5$ & $10.0 *(0-55)$ & $8.1 \pm 11.3$ & $4.5 *(0-63)$ & 0.0238 \\
\hline Margarine (g) & 0.0 & $0.0 *(0-0)$ & $0.1 \pm 0.5$ & $0.0 *(0-3)$ & 0.6938 \\
\hline Nuts (g) & $14.8 \pm 21.0$ & $0.5 *(0-65)$ & $6.7 \pm 11.4$ & $0.0 *(0-64)$ & 0.0455 \\
\hline Mushrooms (g) & $1.7 \pm 10.2$ & $0.0 *(0-70)$ & $1.8 \pm 7.3$ & $0.0 *(0-34)$ & 0.7360 \\
\hline Sugar $(\mathrm{g})$ & $0.7 \pm 3.4$ & $0.0 *(0-20)$ & $0.6 \pm 1.7$ & $0.0 *(0-10)$ & 0.5122 \\
\hline Jam and honey (g) & $2.8 \pm 9.3$ & $0.0 *(0-50)$ & $2.4 \pm 5.0$ & $0.0 *(0-32)$ & 0.0471 \\
\hline Chocolate sweets (g) & $10.8 \pm 29.6$ & $0.0 *(0-133)$ & $11.7 \pm 15.6$ & $1.5 *(0-58)$ & 0.0042 \\
\hline Cakes and cookies (g) & $18.5 \pm 45.3$ & $0.0 *(0-250)$ & $34.1 \pm 44.8$ & $20 *(0-234)$ & 0.0006 \\
\hline Alcoholic beverages (g) & $4.3 \pm 20.7$ & $0.0 *(0-120)$ & $10.7 \pm 45.3$ & $0.0 *(0-33)$ & 0.5517 \\
\hline Sweetened beverages $(\mathrm{g})$ & $10.3 \pm 63.2$ & $0.0 *(0-470)$ & $40.3 \pm 143.8$ & $0.0 *(0-1167)$ & 0.0589 \\
\hline
\end{tabular}

* Nonparametric distribution (verified using the Shapiro-Wilk test; $p<0.05$ ); ${ }^{* *}$ compared using the t-Student test

(for parametric distributions) or the U Mann-Whitney test (for nonparametric distributions).

Table 10. Comparison of other products intake per $1000 \mathrm{kcal}$ in groups of junior health professionals from Poland and Croatia.

\begin{tabular}{|c|c|c|c|c|c|}
\hline & \multicolumn{2}{|c|}{ Polish Group } & \multicolumn{2}{|c|}{ Croatian Group } & \multirow{2}{*}{$p^{* *}$} \\
\hline & Mean \pm SD & Median (Range) & Mean \pm SD & Median (Range) & \\
\hline Vegetables (g) & $215.7 \pm 168.2$ & $198.3 *(0-839.0)$ & $144.8 \pm 119.3$ & $109.1 *(8.4-622.3)$ & 0.0035 \\
\hline Legumes $(\mathrm{g})$ & $11.2 \pm 45.4$ & $0.0 *(0-361.8)$ & $5.4 \pm 18.4$ & $0.0 *(0-144.4)$ & 0.7360 \\
\hline Fruits $(\mathrm{g})$ & $133.7 \pm 102.2$ & $116.1 *(0-604.9)$ & $128.8 \pm 97.7$ & $107.8 *(0-482.9)$ & 0.6203 \\
\hline Potatoes $(\mathrm{g})$ & $20.2 \pm 43.0$ & $0.0 *(0-165.4)$ & $45.6 \pm 49.2$ & $34.4 *(0-217.0)$ & $<0.0001$ \\
\hline Bread $(\mathrm{g})$ & $45.0 \pm 40.2$ & $39.8 *(0-158.6)$ & $46.6 \pm 30.0$ & $43.1 *(0-131.0)$ & 0.4278 \\
\hline Other cereal products (g) & $53.6 \pm 36.3$ & $45.5 *(0-206.4)$ & $54.1 \pm 39.6$ & $45.6 *(0-187.6)$ & 0.8124 \\
\hline Oil (g) & $7.5 \pm 7.0$ & $7.1 *(0-36.8)$ & $4.8 \pm 5.8$ & $3.2 *(0-20.8)$ & 0.0114 \\
\hline Margarine (g) & 0.0 & $0.0 *(0-0)$ & $0.1 \pm 0.4$ & $0.0 *(0-2.7)$ & 0.6938 \\
\hline Nuts $(g)$ & $9.2 \pm 12.1$ & $0.5 *(0-44.8)$ & $4.6 \pm 8.4$ & $0.0 *(0-45.9)$ & 0.0419 \\
\hline Mushrooms (g) & $1.1 \pm 6.5$ & $0.0 *(0-40.8)$ & $1.4 \pm 5.5$ & $0.0 *(0-26.9)$ & 0.7360 \\
\hline Sugar $(\mathrm{g})$ & $0.5 \pm 2.1$ & $0.0 *(0-11.4)$ & $0.3 \pm 0.9$ & $0.0 *(0-4.4)$ & 0.5231 \\
\hline Jam and honey (g) & $1.7 \pm 5.4$ & $0.0 *(0-31.8)$ & $1.7 \pm 3.6$ & $0.0 *(0-21.5)$ & 0.0425 \\
\hline Chocolate sweets (g) & $6.5 \pm 17.6$ & $0.0 *(0-82.3)$ & $8.2 \pm 11.6$ & $0.9 *(0-53.6)$ & 0.0041 \\
\hline Cakes and cookies (g) & $10.8 \pm 25.3$ & $0.0 *(0-141.8)$ & $21.2 \pm 25.1$ & $15.1 *(0-132.5)$ & 0.0004 \\
\hline Alcoholic beverages (g) & $1.9 \pm 9.3$ & $0.0 *(0-52.7)$ & $5.9 \pm 24.7$ & $0.0 *(0-184.2)$ & 0.5530 \\
\hline Sweetened beverages (g) & $6.7 \pm 40.9$ & $0.0 *(0-298.9)$ & $18.1 \pm 47.2$ & $0.0 *(0-311.7)$ & 0.0599 \\
\hline
\end{tabular}

${ }^{*}$ Nonparametric distribution (verified using the Shapiro-Wilk test; $p<0.05$ ); ${ }^{* *}$ compared using the t-Student test (for parametric distributions) or the U Mann-Whitney test (for nonparametric distributions). 
Comparison of the estimated prevalence of inadequate intake of chosen nutrients, while compared with the reference values [61], in groups of junior health professionals from Poland and Croatia is presented in Table 11. In the analyzed group, for folate $(p=0.0023)$, in the Polish group there is a lower risk of inadequate intake, while compared with the Croatian one.

Table 11. Comparison of the estimated prevalence of inadequate intake of chosen nutrients, while compared with the reference values [61], in groups of junior health professionals from Poland and Croatia.

\begin{tabular}{|c|c|c|c|c|c|}
\hline \multirow[b]{2}{*}{ Nutrient * } & \multicolumn{2}{|c|}{ Polish Group } & \multicolumn{2}{|c|}{ Croatian Group } & \multirow[b]{2}{*}{$p^{* *}$} \\
\hline & $\begin{array}{l}\text { Respondents with } \\
\text { Inadequate } \\
\text { Intake-n (\%) }\end{array}$ & $\begin{array}{c}\text { Respondents with } \\
\text { Adequate } \\
\text { Intake-n (\%) }\end{array}$ & $\begin{array}{l}\text { Respondents with } \\
\text { Inadequate } \\
\text { Intake-n (\%) }\end{array}$ & $\begin{array}{c}\text { Respondents with } \\
\text { Adequate } \\
\text { Intake-n (\%) }\end{array}$ & \\
\hline Calcium & $42(60 \%)$ & $28(40 \%)$ & $51(64 \%)$ & $29(36 \%)$ & 0.7616 \\
\hline Iron & $15(21 \%)$ & $55(79 \%)$ & $18(22 \%)$ & $52(78 \%)$ & 0.6901 \\
\hline Folate & $28(40 \%)$ & $42(60 \%)$ & $53(67 \%)$ & $27(33 \%)$ & 0.0023 \\
\hline Vitamin $B_{12}$ & $9(13 \%)$ & $61(87 \%)$ & $13(16 \%)$ & $67(84 \%)$ & 0.7226 \\
\hline Vitamin D & $66(94 \%)$ & $4(6 \%)$ & 79 (99\%) & $1(1 \%)$ & 0.2876 \\
\hline
\end{tabular}

* The following reference values were applied: calcium $(800 \mathrm{mg})$, iron $(8.1 \mathrm{mg})$, folate $(320 \mu \mathrm{g})$, vitamin $\mathrm{B}_{12}(2 \mu \mathrm{g})$, vitamin $\mathrm{D}(10 \mu \mathrm{g}),[61]{ }^{* *}$ compared using the chi ${ }^{2}$ test.

\section{Discussion}

While comparing the nutritional value of the diets and the intake of products between groups of junior health professionals from Poland and Croatia, a number of differences cropped up. While comparing the estimated prevalence of inadequate dietary intake of chosen nutrients, such differences were stated only for folate; however, in both groups, a number of respondents were characterized by an inadequate dietary intake of other nutrients. It should be mentioned that such a situation results from following an improperly balanced diet [63]. As shown by the Food and Agriculture Organization of the United Nations (FAO) [64], in a properly balanced diet that is based on nutritional recommendations, a healthy individual can easily obtain the recommended intake of a majority of nutrients. Consequently, an inadequate intake of specific nutrients may be treated as an indicator of an improperly balanced diet. FAO [65] further emphasizes that a healthy diet associated with an adequate intake of nutrients may be obtained from various combinations of food products.

\subsection{Potential Influence of Health Professional Dietary Habits on Their Patients}

While analyzing the nutritional value of the diets of junior health professionals, it must be above all emphasized that they will educate the Polish and Croatian populations about recommended nutritional behaviors in the future. Consequently, their nutritional inadequacies may generate nutritional inadequacies for a number of individuals and may contribute to dietary health risk factors. This is based on the association between personal dietary habits and attitudes toward preventive counseling, which was observed in a group of physicians and medical students [66]. Furthermore, their own improper dietary behaviors may generate a lack of confidence in the ability to counsel patients regarding lifestyle that is commonly observed [67].

Some patients perceive their dietitian as a role model and focus on both the presented recommendations and the body size or shape; therefore, a number of dietitians are aware that they should also follow the same dietary recommendations that they present to their patients [68]. Furthermore, these educators who include information about they themselves following recommended dietary habits are perceived by patients to be not only healthier, but also more believable and motivating than others [69]. Similarly, the review by Lobelo and Quevedo [70] reported that healthcare providers who are physically active are more likely to provide physical counseling for their patients compared to others. Furthermore, they stated that healthcare providers can play an important role by becoming 
early adopters of physical activity and diet behaviors and, in turn, become role models for their patients and communities [71].

As the presented study was planned to assess the dietary intake of female junior health professionals, their diets were also analyzed from the point of view of future female patients and the diet-related diseases common in this group were analyzed.

\subsection{Dietary Risk Factors for Anemia}

According to the WHO [72], anemia, in industrialized countries, is diagnosed for one in ten women and for one in four pregnant women. However, the systematic analysis of population-representative data by Stevens et al. [73] indicated, based on hemoglobin concentration, a higher frequency of $29 \%$ in nonpregnant women and $38 \%$ in pregnant ones. This problem may lead to significant health-related consequences such as increased mortality [74].

In the presented study, a higher intake of iron and folate was observed in the Polish group compared to the Croatian group. Also, such an observation was noted in case of intake of vitamin $B_{12}$ per $1000 \mathrm{kcal}$. A higher iron and vitamin $B_{12}$ intake for Polish women was observed despite a higher intake of cold cuts (which are within their sources) in Croatian women. However, the frequency of inadequate intake was rather high for both countries. Moreover, a higher frequency of inadequate intake for folate was stated more commonly for Croatian women than Polish ones, that may have resulted from the lower vegetable intake in Croatian women. The observations correspond with the results of other studies indicating inadequate intake of iron, for Polish [75] and Croatian young women [76], as well as of folate, for Polish [77] and Croatian young women [76].

Based on the assessment of intake adequacy, the risk of anemia for young women in both countries is quite high. Furthermore, for Croatia, it may be even higher than that for Poland despite a higher intake of cold cuts. Although the intake of traditional meat products is high in Croatia, corresponding to high intake of cold cuts reported in this study, it mainly results in high fat intake [78]; however, it may not influence iron intake significantly.

\subsection{Dietary Risk Factors for Osteoporosis}

Osteoporosis is another disease that is commonly more observed in women than men because it is estimated that one in two women, but only one in three men, will experience osteoporotic fractures [79]. However, the prevention of osteoporosis is especially important because progressive bone mass loss is observed after the age of 30 [80], contributing to the high risk for osteoporosis [81].

In the presented study, a higher intake of calcium per $1000 \mathrm{kcal}$ was observed in the Polish group compared to the Croatian group. This may have been associated with a higher cottage cheese intake in Polish women. However, a very low intake was observed for vitamin D in both groups; therefore, for both countries, the frequency of inadequate intake was high. The observations correspond with inadequate intake of calcium, observed for Polish [82] and Croatian young women [83]; however, some studies reported higher intake of calcium in Croatia [84]. Furthermore, the inadequate intake of vitamin D is commonly stated for both Polish [85] and Croatian [86] young women [47].

Based on the conducted assessment of the adequacy of intake, it must be stated that the risk of osteoporosis for young women in both countries is high and comparable, resulting primarily from the inadequate intake of vitamin D. Moreover, as the vitamin D status both in Poland [59] and Croatia [60] is commonly not adequate, due to insufficient sunshine exposure, it must be emphasized that the inadequate vitamin D intake probably is not compensated by the endogenous synthesis. Taking it into account, even if the inadequate intake of calcium is not so common, the risk of osteoporosis must be stated.

Taking into account, that it is stated, that health professionals commonly do not have proper healthy lifestyle behaviors that impact chronic diseases, they are often not prepared properly for preventive counseling with their patients, and do not present dietary recommendation to their patients [86], so the necessary actions should be taken to obtain a properly balanced diet following. It may be 
stated, that adequate nutritional education is needed, in order to improve their nutritional behaviors, embolden them to educate their patients, and increase the number of patients being counseled.

Although the present study provided new insight for identifying potential dietary health risks for women in Poland and Croatia, some limitations must be noted. For further studies, it would be valuable to conduct similar assessments in groups consisting of other nutritional knowledge providers (including physicians); male educators should also be analyzed. It should be emphasized that, both in Poland and Croatia, nutritional faculties are not present only in capital cities, so including specialists from other regions would allow us to gain a broader perspective.

\section{Conclusions}

A number of differences in the nutrients and food products intake between the Polish and the Croatian group of junior health professionals may result in various dietary health risks for women in these countries. For anemia, compared to Polish women, a higher risk may be indicated for Croatian women because of lower iron, folate, and vitamin $\mathrm{B}_{12}$ intake, and more common inadequate intake of folate. For osteoporosis, similar risks may be indicated for Polish and Croatian women because of very low vitamin $\mathrm{D}$ intake in both countries. Therefore, adequate nutritional education of junior health professionals is necessary.

Author Contributions: Conceptualization, D.G. (Dominika Głąbska), V.R., D.G. (Dominika Guzek); methodology, D.G. (Dominika Głąbska); formal analysis, D.G. (Dominika Głąbska), V.R., D.G. (Dominika Guzek), K.J.; investigation, V.R., K.J., S.B., E.P.; data curation, D.G. (Dominika Głąbska), V.R., D.G. (Dominika Guzek), K.J., S.B., Z.G., E.P.; writing-original draft preparation, D.G. (Dominika Głąbska), V.R., D.G. (Dominika Guzek), K.J., S.B., Z.G., E.P.; writing-review and editing, D.G. (Dominika Głąbska), V.R., D.G. (Dominika Guzek), K.J., S.B., Z.G., E.P.; project administration, D.G. (Dominika Głąbska), V.R.

Funding: The research was financed by the Polish Ministry of Science and Higher Education with funds from the Faculty of Human Nutrition and Consumer Sciences, Warsaw University of Life Sciences (WULS), for scientific research.

Conflicts of Interest: The authors declare no conflict of interest.

\section{References}

1. World Health Organization (WHO). Ten Top Issues for Women's Health. Available online: https://www.who. int/life-course/news/commentaries/2015-intl-womens-day/en/ (accessed on 29 August 2019).

2. World Health Organization (WHO). Strategy on women's health and well-being in the WHO European Region. In Proceedings of the Regional Committee for Europe, 66th Session Copenhagen, Copenhagen, Denmark, 12-15 September 2016.

3. Jonas, K.; Crutzen, R.; Krumeich, A.; Roman, N.; van den Borne, B.; Reddy, P. Healthcare workers' beliefs, motivations and behaviours affecting adequate provision of sexual and reproductive healthcare services to adolescents in Cape Town, South Africa: A qualitative study. BMC Health Serv. Res. 2018, 18, 109. [CrossRef] [PubMed]

4. Cao, R.; Stone, T.E.; Petrini, M.A.; Turale, S. Nurses' perceptions of health beliefs and impact on teaching and practice: A Q-sort study. Int. Nurs. Rev. 2018, 65, 131-144. [CrossRef] [PubMed]

5. Puhl, R.M.; Gold, J.A.; Luedicke, J.; DePierre, J.A. The effect of physicians' body weight on patient attitudes: Implications for physician selection, trust and adherence to medical advice. Int. J. Obes. 2013, 37, 1415-1421. [CrossRef] [PubMed]

6. Adamski, M.; Gibson, S.; Leech, M.; Truby, H. Are doctors nutritionists? What is the role of doctors in providing nutrition advice? Nutr. Bull. 2018, 43, 147-152. [CrossRef]

7. Ahmed, A.; Jabbar, A.; Zuberi, L.; Islam, M.; Shamim, K. Diabetes related knowledge among residents and nurses: A multicenter study in Karachi, Pakistan. BMC Endocr. Disord. 2012, 12, 18. [CrossRef] [PubMed]

8. Findlow, L.A.; McDowell, J.R.S. Determining registered nurses' knowledge of diabetes mellitus. J. Diabetes Nurs. 2002, 6, 170-175.

9. Irazusta, A.; Gil, S.; Ruiz, F.; Gondra, J.; Jauregi, A.; Irazusta, J.; Gil, J. Exercise, physical fitness, and dietary habits of first-year female nursing students. Biol. Res. Nurs. 2006, 7, 175-186. [CrossRef] [PubMed] 
10. Albuquerque, A.G.; Pontes, C.M.; Osorio, M.M. Knowledge of educators and dieticians on food and nutrition education in the school environment. Rev. Nutr. 2013, 26, 291-300. [CrossRef]

11. Schaefer, J.T.; Zullo, M.D. US Registered Dietitian Nutritionists' Knowledge and Attitudes of Intuitive Eating and Use of Various Weight Management Practices. J. Acad. Nutr. Diet. 2017, 117, 1419-1428. [CrossRef]

12. Winham, D.M.; Hutchins, A.M.; Thompson, S.V.; Dougherty, M.K. Arizona Registered Dietitians Show Gaps in Knowledge of Bean Health Benefits. Nutrients 2018, 10, 52. [CrossRef]

13. Fredericks, S.C.; Hamilton, C. Dietary Intakes of Registered Dietitians. J. Amer. Diet. Ass. 1996, 96, 25. [CrossRef]

14. Kowalze, K.; Turyk, Z.; Drywień, M. Nutrition of students from dietetics profile education in the Siedlce University of Natural Sciences and Humanities compared with students from other academic centres. Rocz. Panstw. Zakl. Hig. 2016, 67, 51-58.

15. Mealha, V.; Ferreira, C.; Guerra, I.; Ravasco, P. Students of dietetics \& nutrition; a high risk group for eating disorders? Nutr. Hosp. 2013, 28, 1558-1566. [CrossRef] [PubMed]

16. Almajwal, A.M. Stress, shift duty, and eating behavior among nurses in Central Saudi Arabia. Saudi Med. J. 2016, 37, 191-198. [CrossRef] [PubMed]

17. Głabska, D.; Włodarek, D. Analysis of the declared nutritional behaviours in a group of diabetology nurses educating patients about diabetes diet therapy. Rocz. Panstw. Zakl. Hig. 2015, 66, 345-351. [PubMed]

18. Bleich, S.N.; Bennett, W.L.; Gudzune, K.A.; Cooper, L.A. Impact of physician BMI on obesity care and beliefs. Obesity 2012, 20, 999-1005. [CrossRef] [PubMed]

19. Gupta, S. Dietary Practices and Nutritional Profile of Female Nurses from Government Hospitals in Delhi, India. Iran. J. Nurs. Midwifery Res. 2017, 22, 348-353. [CrossRef] [PubMed]

20. Miller, S.K.; Alpert, P.T.; Cross, C.L. Overweight and obesity in nurses, advanced practice nurses, and nurse educators. J. Am. Acad. Nurse Pract. 2008, 20, 259-265. [CrossRef]

21. Tremelling, K.; Sandon, L.; Vega, G.L.; McAdams, C.J. Orthorexia Nervosa and Eating Disorder Symptoms in Registered Dietitian Nutritionists in the United States. J. Acad. Nutr. Diet. 2017, 117, 1612-1617. [CrossRef]

22. Asil, E.; Sürücüoğlu, M.S. Orthorexia Nervosa in Turkish Dietitians. Ecol. Food Nutr. 2015, 54, $303-313$. [CrossRef]

23. Przeor, M.; Goluch-Koniuszy, Z. Ocena stanu odżywienia oraz sposobu żywienia pielęgniarek będących $\mathrm{w}$ okresie okołomenopauzalnym pracujących w systemie zmianowym. [Evaluation of nutrition and diet of nurses during perimenopause while working in a shift system]. Prob. Hig. Epidemiol. 2013, 94, 797-801. (In Polish)

24. Stefańska, E.; Ostrowska, L.; Radziejewska, I.; Kardasz, M. Sposób żywienia studentów Uniwersytetu Medycznego w Białymstoku w zależności od miejsca zamieszkania w trakcie studiów. [Mode of nutrition in students of the Medical University of Bialystok according to their place of residence during the study period]. Prob. Hig. Epidemiol. 2010, 91, 585-590. (In Polish)

25. Kubiak, J.; Różańska, D.; Regulska-Ilow, B.; Kawicka, A.; Salomon, A.; Konikowska, K. Ocena jakości diet studentek dietetyki na podstawie wskaźnika DQI (Diet Quality Index). [Assessment of the quality of the dietetics students diets based on the diet quality index (DQI). Bromat. Chem. Toksykol. 2015, 3, 429-432. (In Polish)

26. Warner, M.J.; Kamran, M.T. Anemia, Iron Deficiency. Available online: https://www.ncbi.nlm.nih.gov/books/ NBK448065/ (accessed on 29 August 2019).

27. Alswat, K.A. Gender Disparities in Osteoporosis. J. Clin. Med. Res. 2017, 9, 382-387. [CrossRef]

28. Toxqui, L.; Vaquero, M.P. Chronic iron deficiency as an emerging risk factor for osteoporosis: A hypothesis. Nutrients 2015, 7, 2324-2344. [CrossRef]

29. World Health Organization (WHO). Haemoglobin Concentrations for the Diagnosis of Anaemia and Assessment of Severity. Available online: https://www.who.int/vmnis/indicators/haemoglobin.pdf (accessed on 29 August 2019).

30. World Health Organization (WHO). Focusing on Anaemia-Towards an Integrated Approach for Effective Anaemia Control. Available online: https:/www.who.int/nutrition/publications/micronutrients/ WHOandUNICEF_statement_anaemia/en (accessed on 29 August 2019).

31. World Health Organization (WHO). The Global Prevalence of Anaemia in 2011; World Health Organization: Geneva, Switzerland, 2015.

32. DeLoughery, T.G. Iron Deficiency Anemia. Med. Clin. N. Am. 2017, 101, 319-332. [CrossRef] 
33. O'Malley, E.G.; Cawley, S.; Kennedy, R.A.K.; Reynolds, C.M.E.; Molloy, A.; Turner, M.J. Maternal anaemia and folate intake in early pregnancy. J. Public Health 2018, 40, 296-302. [CrossRef]

34. Green, R. Vitamin B12 deficiency from the perspective of a practicing hematologist. Blood 2017, 129, $2603-2611$. [CrossRef]

35. World Health Organization, Centers for Disease Control and Prevention. Assessing the Iron Status of Populations. Available online: https://www.who.int/nutrition/publications/micronutrients/anaemia_iron_ deficiency/9789241596107/en/ (accessed on 4 August 2019).

36. International Osteoporosis Foundation (IOF). Facts and Statistics. Available online: https://www. iofbonehealth.org/facts-statistics (accessed on 29 August 2019).

37. Svedbom, A.; Hernlund, E.; Ivergård, M.; Compston, J.; Cooper, C.; Stenmark, J.; McCloskey, E.V.; Jönsson, B.; Kanis, J.A.; EU Review Panel of IOF. Osteoporosis in the European Union: A compendium of country-specific reports. Arch. Osteoporos. 2013, 8, 137. [CrossRef]

38. Cvijetić Avdagić, S.; Grazio, S.; Kaštelan, D.; Koršić, M. Epidemiologija osteoporozę. Arhiv. za higijenu rada $i$ toksikologiju 2007, 58, 13-18. [CrossRef]

39. Giljević, Z. Znaaj problema osteoporoze u Hrvatskoj. In Proceedings of the Svjetski Dan Osteoporoze, Zagreb, Croatia, 20-22 October 2005; Sveučilište u Zagrebu: Zagreb, Croatia, 2005.

40. Grazio, S.; Korsić, M.; Jajić, I. Prevalence of vertebral fractures in an urban population in Croatia aged fifty and older. Wien. Klin. Wochenschr. 2005, 117, 42-47. [CrossRef]

41. Tai, V.; Leung, W.; Grey, A.; Reid, I.R.; Bolland, M.J. Calcium intake and bone mineral density: Systematic review and meta-analysis. BMJ 2015, 351, 4183. [CrossRef]

42. Laird, E.; Ward, M.; McSorley, E.; Strain, J.J.; Wallace, J. Vitamin D and bone health: Potential mechanisms. Nutrients 2010, 2, 693-724. [CrossRef]

43. Drewnowski, A.; Dwyer, J.; King, J.C.; Weaver, C.M. A proposed nutrient density score that includes food groups and nutrients to better align with dietary guidance. Nutr. Rev. 2019, 77, 404-416. [CrossRef]

44. Metges, C.C.; Barth, C.A. Metabolic consequences of a high dietary-protein intake in adulthood: Assessment of the available evidence. J. Nutr. 2000, 130, 886-889. [CrossRef]

45. Springmann, M.; Wiebe, K.; Mason-D'Croz, D.; Sulser, T.B.; Rayner, M.; Scarborough, P. Health and nutritional aspects of sustainable diet strategies and their association with environmental impacts: A global modelling analysis with country-level detail. Lancet Planet. Health 2018, 2, 451-461. [CrossRef]

46. Głabska, D.; Guzek, D.; Slązak, J.; Włodarek, D. Assessing the Validity and Reproducibility of an Iron Dietary Intake Questionnaire Conducted in a Group of Young Polish Women. Nutrients 2017, 9, 199. [CrossRef]

47. Głąbska, D.; Uroić, V.; Guzek, D.; Pavić, E.; Bival, S.; Jaworska, K.; Giljević, Z.; Lange, E. The Possibility of Applying the Vitamin D Brief Food Frequency Questionnaire as a Tool for a Country with No Vitamin D Data in Food Composition Tables. Nutrients 2018, 10, 1278. [CrossRef]

48. Kunachowicz, H.; Nadolna, J.; Przygoda, B.; Iwanow, K. (Eds.) Food Composition Tables; PZWL: Warsaw, Poland, 2005. (In Polish)

49. Głabska, D.; Jusinska, M. Analysis of the choice of food products and the energy value of diets of female middle- and long-distance runners depending on the self-assessment of their nutritional habits. Rocz. Panstw. Zakl. Hig. 2018, 69, 155-163.

50. Committee on the Consequences of Sodium Reduction in Populations; Food and Nutrition Board; Board on Population Health and Public Health Practice; Institute of Medicine; Strom, B.L.; Yaktine, A.L.; Oria, M. (Eds.) Sodium Intake in Populations: Assessment of Evidence; National Academies Press: Washington, DC, USA, 2013. Available online: https://www.ncbi.nlm.nih.gov/books/NBK201516/ (accessed on 5 September 2019).

51. Chen, S.L.; Dahl, C.; Meyer, H.E.; Madar, A.A. Estimation of Salt Intake Assessed by 24-Hour Urinary Sodium Excretion among Somali Adults in Oslo, Norway. Nutrients 2018, 10, 900. [CrossRef]

52. Cogswell, M.E.; Maalouf, J.; Elliott, P.; Loria, C.M.; Patel, S.; Bowman, B.A. Use of Urine Biomarkers to Assess Sodium Intake: Challenges and Opportunities. Annu. Rev. Nutr. 2015, 35, 349-387. [CrossRef]

53. Vega-Vega, O.; Fonseca-Correa, J.I.; Mendoza-De la Garza, A.; Rincón-Pedrero, R.; Espinosa-Cuevas, A.; Baeza-Arias, Y.; Dary, O.; Herrero-Bervera, B.; Nieves-Anaya, I.; Correa-Rotter, R. Contemporary Dietary Intake: Too Much Sodium, Not Enough Potassium, yet Sufficient Iodine: The SALMEX Cohort Results. Nutrients 2018, 10, 816. [CrossRef]

54. Johnson-Wimbley, T.D.; Graham, D.Y. Diagnosis and management of iron deficiency anemia in the 21st century. Therap. Adv. Gastroenterol. 2011, 4, 177-184. [CrossRef] 
55. Sunyecz, J.A. The use of calcium and vitamin D in the management of osteoporosis. Ther. Clin. Risk Manag. 2008, 4, 827-836. [CrossRef]

56. European Food Safety Authority (EFSA). Scientific opinion on the tolerable upper intake level of vitamin D. EFSA J. 2012, 10, 2813.

57. Van Schoor, N.M.; Lips, P. Worldwide vitamin D status. Best Pract. Res. Clin. Endocrinol. Metab. 2011, 25, 671-680. [CrossRef]

58. Cashman, K.D.; Dowling, K.G.; Škrabáková, Z.; Gonzalez-Gross, M.; Valtueña, J.; De Henauw, S.; Moreno, L.; Damsgaard, C.T.; Michaelsen, K.F.; Mølgaard, C.; et al. Vitamin D deficiency in Europe: Pandemic? Am. J. Clin. Nutr. 2016, 103, 1033-1044. [CrossRef]

59. Płudowski, P.; Ducki, C.; Konstantynowicz, J.; Jaworski, M. Vitamin D status in Poland. Pol. Arch. Med. Wewn. 2016, 126, 530-539. [CrossRef]

60. Colić Barić, I.; Keser, I.; Bituh, M.; Rumbak, I.; Rumora Samarin, I.; Beljan, K.; Gežin, L.; Lazinica, G. Vitamin $D$ Status and Prevalence of Inadequacy in Croatian Population; Book of Abstracts of 4th International Congress of Nutritionists: Zadar, Hrvatska, 2016; p. 97.

61. Nutrient Recommendations: Dietary Reference Intakes (DRI). Available online: https://ods.od.nih.gov/ Health_Information/Dietary_Reference_Intakes.aspx (accessed on 4 August 2019).

62. Institute of Medicine. Dietary Reference Intakes: Applications in Dietary Assessment; The National Academies Press: Washington, DC, USA, 2000. Available online: https://www.nap.edu/catalog/9956/dietary-referenceintakes-applications-in-dietary-assessment (accessed on 4 August 2019). [CrossRef]

63. Shao, A.; Drewnowski, A.; Willcox, D.C.; Krämer, L.; Lausted, C.; Eggersdorfer, M.; Mathers, J.; Bell, J.D.; Randolph, R.K.; Witkamp, R.; et al. Optimal nutrition and the ever-changing dietary landscape: A conference report. Eur. J. Nutr. 2017, 56, 1-21. [CrossRef]

64. Food and Agriculture Organization of the United Nations (FAO). Food-Based Dietary Guidelines. Available online: http://www.fao.org/nutrition/education/food-dietary-guidelines/en/ (accessed on 29 August 2019).

65. Food and Agriculture Organization of the United Nations (FAO). Food-Based Approaches to Meeting Vitamin and Mineral Needs. Available online: http://www.fao.org/3/y2809e/y2809e08.htm (accessed on 29 August 2019).

66. Duperly, J.; Lobelo, F.; Segura, C.; Sarmiento, F.; Herrera, D.; Sarmiento, O.L.; Frank, E. The association between Colombian medical students' healthy personal habits and a positive attitude toward preventive counseling: Cross-sectional analyses. BMC Public Health 2009, 9, 218. [CrossRef]

67. Howe, M.; Leidel, A.; Krishnan, S.M.; Weber, A.; Rubenfire, M.; Jackson, E.A. Patient-related diet and exercise counseling: Do providers' own lifestyle habits matter? Prev. Cardiol. 2010, 13, 180-185. [CrossRef]

68. Cant, R.P. Communication competence within dietetics: dietitians' and clients' views about the unspoken dialogue-the impact of personal presentation. J. Hum. Nutr. Diet. 2009, 22, 504-510. [CrossRef]

69. Frank, E.; Breyan, J.; Elon, L. Physician disclosure of healthy personal behaviors improves credibility and ability to motivate. Arch. Fam. Med. 2000, 9, 287-290. [CrossRef]

70. Lobelo, F.; de Quevedo, I.G. The Evidence in Support of Physicians and Health Care Providers as Physical Activity Role Models. Am. J. Lifestyle Med. 2016, 10, 36-52. [CrossRef]

71. Lobelo, F.; de Quevedo, I.G. Weighing in on residents' body mass index: A teachable moment for physicians and patients alike? J. Grad. Med. Educ. 2013, 5, 521-523. [CrossRef]

72. World Health Organization (WHO). Iron Deficiency Anaemia Assessment, Prevention and Control a Guide for Programme Managers; World Health Organization: Geneva, Switzerland, 2001.

73. Stevens, G.A.; Finucane, M.M.; De-Regil, L.M.; Paciorek, C.J.; Flaxman, S.R.; Branca, F.; Peña-Rosas, J.P.; Bhutta, Z.A.; Ezzati, M.; Nutrition Impact Model Study Group (Anaemia). Global, regional, and national trends in haemoglobin concentration and prevalence of total and severe anaemia in children and pregnant and non-pregnant women for 1995-2011: A systematic analysis of population-representative data. Lancet Glob. Health 2013, 1, 16-25. [CrossRef]

74. Khaskheli, M.N.; Baloch, S.; Sheeba, A.; Baloch, S.; Khaskheli, F.K. Iron deficiency anaemia is still a major killer of pregnant women. Pak. J. Med. Sci. 2016, 32, 630-634. [CrossRef]

75. Skolmowska, D.; Głąsska, D. Analysis of Heme and Non-Heme Iron Intake and Iron Dietary Sources in Adolescent Menstruating Females in a National Polish Sample. Nutrients 2019, 11, 1049. [CrossRef]

76. Satalic, Z.; Baric, I.C.; Keser, I. Diet quality in Croatian university students: Energy, macronutrient and micronutrient intakes according to gender. Int. J. Food Sci. Nutr. 2007, 58, 398-410. [CrossRef] 
77. Głąbska, D.; Książek, A.; Guzek, D. Development and Validation of the Brief Folate-Specific Food Frequency Questionnaire for Young Women's Diet Assessment. Int. J. Environ. Res. Public Health 2017, 14, 1574. [CrossRef]

78. Lešić, T.; Krešić, G.; Koprivnjak, O.; Kovečević, D.; Gross-Bošković, A.; Sokolić, D.; Jurković, M.; Pleadin, J. Estimation of dietary fat intake via the consumption of traditional meat products. Croat. J. Food Technol. Biotechnol. Nutr. 2016, 11, 138-144.

79. Ross, P.D. Osteoporosis. Frequency, consequences, and risk factors. Arch. Intern. Med. 1996, 156, $1399-1411$. [CrossRef]

80. Benjamin, R.M. Bone health: Preventing osteoporosis. J. Am. Diet. Assoc. 2010, 110, 498. [CrossRef]

81. Osterhoff, G.; Morgan, E.F.; Shefelbine, S.J.; Karim, L.; McNamara, L.M.; Augat, P. Bone mechanical properties and changes with osteoporosis. Injury 2016, 2, 11-20. [CrossRef]

82. Lewiński, A.; Skowrońska-Jóźwiak, E. Calcium and vitamin D supply in Polish population-facts and myths. Ann. Agric. Environ. Med. 2014, 21, 455-456.

83. Mandić-Puljek, M.; Mandić, M.L.; Perl, A.; Kenjerić, D. Calcium intake, food sources and seasonal variations in eastern Croatia. Coll. Antropol. 2005, 29, 503-507.

84. Douglas, C.C.; Rumbak, I.; Barić, I.C.; Kovačina, M.; Piasek, M.; Ilich, J.Z. Are new generations of female college-student populations meeting calcium requirements: Comparison of American and Croatian female students. Nutrients 2010, 2, 599-610. [CrossRef]

85. Wyka, J.; Żechałko-Czajkowska, A. Vitamins and minerals in diets of first year female students of the Wrocław university of environmental and life sciences. Pol. J. Food Nutr. Sci. 2008, 58, 131-137.

86. Hidalgo, K.D.; Mielke, G.I.; Parra, D.C.; Lobelo, F.; Simões, E.J.; Gomes, G.O.; Florindo, A.A.; Bracco, M.; Moura, L.; Brownson, R.C.; et al. Health promoting practices and personal lifestyle behaviors of Brazilian health professionals. BMC Public Health 2016, 16, 1114. [CrossRef]

(C) 2019 by the authors. Licensee MDPI, Basel, Switzerland. This article is an open access article distributed under the terms and conditions of the Creative Commons Attribution (CC BY) license (http://creativecommons.org/licenses/by/4.0/). 